한국지역사회생활과학회지

Korean J. Community Living Science

22(3): 429 444, 2011

$$
\begin{gathered}
\text { 생태체계적 관점에서 본 생애주기별 자살생각의 } \\
\text { 위험요인과 보호요인 } \\
\text { 김 윤 정 } \\
\text { 한서대학교 노인복지학과 }
\end{gathered}
$$

\title{
Risk and Protection Factor Related to Suicide Ideation in Each Life Course based on an Ecological-system Perspective
}

\author{
Kim, Yun Jeong
}

Dept. of Elderly Welfare Hanseo University, Seosan, Korea

\begin{abstract}
The objective of this study was to identify the risk factor and protection factor related to suicide ideation in each life course based on an ecological-system perspective. A questionnaire was carried out for 393 adolescents, 473 adults and 376 aged men living nationwide. The results are as follows. First, the suicide ideation was low with 1.78 points in the full mark of 5 points. Second, the difference in suicide ideation, depression, hopelessness, stress in the organic system variables, family solidarity in the micro system variables, intermediate system variables, residence, the existence/inexistence of counselling center and the influence of mass media in mezo system variables in each life course were significant. Third, the relative influence of organic system variables on the suicide ideation were largest in all life courses. Further, the depression and the influence of mass media in all life courses were a risk factor of suicide ideation and stress was also a risk factor of suicide ideation in the case of adolescents and the aged. When examining protection factors of suicide ideation, family solidarity, minute as it is, works as the protection factor of suicide ideation in the case of adolescents. For the adults, living in a metropolis was a protection factor from suicide ideation. For the aged, family solidarity, family history of suicide and adult children's attention to their friends and neighbors (intermediate system variable) were protection factors from suicide ideation. I suggested that policy, service, counseling and educational program proper to each life course were necessary to lower risk factors of suicide ideation and to improve protection factors.
\end{abstract}

Key words: suicide ideation, ecological-system perspective, life course, risk factor, protection factor

이 논문은 2009년 정부재원(교육과학기술부 인문사회역량강화사업비)으로 한국연구재단의 지원을 받아 수행되었음 (NRF-2009-327-B00468). 


\section{I. 서론}

\section{1. 연구의 필요성}

자살이란 의도적으로 혹은 그 외의 부수적 의 도로 죽음을 착수하는 것으로, 의식적, 의도적, 의지적 행위이며, 자살생각, 자살시도, 자살행위 에 이르는 연속적 개념이다(Harwood \& Jacoby 2000). Carison과 Cantwell(이정윤, 허재홍에서 재 인용 2003)은 일반인들이 지닌 자살에 대한 생각 을 조사하고 후속 연구로서 자살 시도율을 조사 한 결과, 자살에 대한 생각이 심각했던 사람들의 $42 \%$ 와 경미했던 사람의 $34 \%$ 가 후에 자살을 시 도했던 것으로 나타났다. 그러나 자살에 대한 생 각을 전혀 하지 않았던 집단에서는 단 한 명도 자살을 시도하지 않은 것으로 나타났다. 즉, 자살 생각은 엄격한 의미에서 자살과 동일한 의미는 아니지만 논리적으로 자살생각이 자살시도나 자 살행위에 앞서는 것으로, 많은 연구자들은 자살 행위를 연구함에 있어 자살생각을 살펴보고 있으 며, 자살생각수준이 높을수록 자살을 기도하는 비율도 높아진다(강은정 2005; 임수영 1996; Lester 1989). 따라서 자살과 관련된 위험요인과 보호요 인을 파악하고자 하는 본 연구에서는 자살생각에 초점을 두었다.

자살은 지극히 개인적인 문제 일 수 있으나, 사회적 현상과 함께 나타나기 때문에 사회현상의 하나로 볼 수 있어 사회적 관심이 집중되고 있 다. 특히 자살율이 매년 급증하고 있는데, 2005년 도에는 인구 10 만명당 자살율이 24.7 명이었으나 2009년도에는 31명으로 증가하였다(통계청 2011). 이처럼 자살이 사회적으로 널리 퍼지고 있어 현 재 우리나라의 자살은 상당한 사회적 문제임을 알 수 있다. 특히 자살은 어느 특정 연령대의 문 제라기보다는 전 연령대에 걸친 문제이다. 치명 적인 자살율은 연령이 증가 할수록 증가하여 70 대 이상의 자살율이 20 대 자살율에 4 배에 달하지 만(오진경 등 2005), 자살 시도율이 가장 높은 시 기는 청소년 시기(김순규 2008)이며, 청소년과 성 인의 사망 원인 중에서 자살이 차지하는 비중이 높다. 따라서 자살은 모든 연령대에서도 일어날
수 있는 사건으로 전 연령대에 걸쳐 생애주기별 로 자살생각 관련 요인을 살펴볼 필요가 있다.

또한, 자살은 어느 특정지역에 국한되는 사안 은 아니다. 인구 10 만명 당 자살율을 살펴보면, 강원, 충북, 충남, 전북, 제주는 전국 평균 수준인 31 명을 넘고 있으며, 대전, 부산과 경북, 경남은 전국평균 수준이었고, 서울, 대구, 광주, 울산, 경 기, 전남은 평균 수준보다 낮다. 그 중에서 충남 이 45.8 명으로 가장 자살율이 높으며 울산이 24.8 명으로 가장 낮다(통계청 2011). 따라서 자살생각 의 실태를 알아보고 이를 근간으로 하여 자살생 각 위험요인과 보호요인을 파악하기 위한 본 연 구에서는 전국에 걸친 표본조사를 하고자 한다.

우리사회에서 자살율이 증가함에 따라 자살과 관련된 실증연구들이 상당수 발표되었고 자살과 관련된 정보가 많이 축적되었다. 그러나 이러한 선행연구는 다음 몇 가지의 제한점이 있다. 첫째, 통계청 자료(김형수 2006; 오진경 등 2005)나 보 건지표 가구조사자료(신상진 - 조영태 2007), 국민 건강-영양조사(강은정 2005), 사건기록지의 내용 분석(김효창 2006) 등의 2차(secondary)자료를 이 용함으로써, 주로 사회인구학적 특성의 차이에 초점을 두어 연구하고 있다. 따라서 각 집단의 자살생각에 영향을 미칠 수 있는 환경적 변수나 심리적 변수를 놓치고 있다. 둘째로는 여러 연령 층에 관한 연구는 많으나 전 연령층을 모두 포괄 하고 있지는 못하고 있다. 주로 청소년이나 노인 등 단일집단을 대상으로 하거나(김순규 2008; 김 효정 - 정미애 2010; 송영달 등 2010), 노인과 청 소년을 비교(김현순·김병석 2008)하는 정도로 이루어지고 있다. 특히 우리 사회의 중추적인 역 할을 하고 있는 성인 및 중장년층의 자살은 그로 인한 사회와 가족에 미치는 영향이 클 수 있으나 이들의 자살생각에 대한 연구는 소수(강모성 등 2008; 강은정 2005; 김효창 2006; 오진경 등 2005)에 그치고 있다. 셋째로는 자살위험을 감소 시킬 수 있는 구체적인 방안들을 제시하지는 못 하고 있다는 점이다. 김순규(2008)는 자살의 위험 요인과 보호요인으로 나누어 분석하였으나 청소 년시기에 한정되고 있고, 김현순과 김병석(2008), 김형수(2006)의 연구는 청소년과 노인의 자살율 
을 감소시키기 위한 정책적 제언을 하는 수준에 머물러 있다.

한편, 자살은 개인의 심리적, 신체적 요인 뿐 만 아니라 정치적, 사회적, 경제적, 문화적 요인 에 의해서도 발생되기 때문에, 자살의 원인에 대 해서는 각 학문적 관점에 따라 다양하게 제시되 고 있다. 자살은 개인적인 요인만이 아니라 가족 관계, 사회 환경과의 관계, 사회 구조적인 요인 등이 통합적으로 영향을 미치는 사건이기 때문이 다. 예를 들어 경제학적 관점에서는 소득수준이 나 빈곤수준, 실업(노용환 2005; 장지연 - 신동균 2010)을, 심리학적 관점에서는 우울이나 스트레 스, 절망감(이귀행 2004; Baumeister 1990)을, 사회 통합이론에서는 배우자가 없거나 직업이 없고, 종교가 없는 등 사회통합정도(김형수 2006)를 자 살의 원인으로 언급하고 있다. 그럼에도 선행연 구자들은 어느 하나의 이론적 관점에 초점을 두 고 연구를 하고 있는 경향이다. 이는 자료의 문 제라든지 연구자의 관점에 따른 제한점이긴 하지 만 이러한 제한점으로 인해 자살에 영향을 미칠 수 있는 다양한 차원의 요인들을 모두 밝혀내고 있지 못하고 있어 본 연구에서는 자살생각과 관 련된 다양한 차원을 모두 포괄할 수 있는 생태체 계적 관점에서 생애주기별 자살생각 관련변수를 파악하고자 한다.

종합해 보면 자살생각과 관련된 기존의 연구 들은 2 차적인 자료를 사용함으로 자살생각의 심 리적인 변수를 놓치고 있으며, 청소년이나 노년 층에 대한 관심은 높았으나 성인의 자살생각에 대한 관심은 부족하였고, 다양한 차원에서 영향 을 받는 자살생각 관련변인을 모두 포괄적으로 살펴보지 못하였다. 또한 자살생각의 위험요인에 연구의 초점을 둠으로서 자살생각을 낮출 수 있 는 방안을 제안하는데도 제한점이 있었다. 따라 서 성인을 포함하여 모든 생애주기를 포함하고 자살생각과 관련된 다양한 변수를 포괄적으로 파 악하기 위해서는 생태체계적 관점을 사용하며, 자살생각을 낮출 수 있는 구체적인 방안을 제시 하기 위해서는 자살생각의 보호요인과 위험요인 을 살펴볼 필요가 있다.

\section{2. 연구의 목적}

본 연구에서는 전국에 거주하는 청소년, 성인, 노인을 대상으로 생태체계적 접근을 기반으로 하 여 자살생각과 관련된 단편적인 변수고찰이 아닌 포괄적인 원인을 살펴봄으로서 개인적 수준, 사 회적 관계, 개인이 속한 지역사회 등 여러 체계 로부터 영향을 받는 자살생각의 위험요인과 보호 요인을 규명하고자 한다. 특히 모든 생애에 있어 공통적인 자살생각의 위험요인과 보호요인은 무 엇이고, 특정 생애주기에만 영향을 미치는 자살 생각의 위험요인과 보호요인은 무엇인가를 파악 하고자 한다. 구체적인 연구목적은 다음과 같다. 첫째, 생애주기별 자살생각실태를 파악한다. 둘 째, 생애주기에 따른 생태체계변수의 차이를 파 악한다. 셋째, 생애주기별 자살생각에 영향을 미 치는 생태체계변수의 위험요인과 보호요인을 파 악한다.

\section{II. 이론적 배경}

\section{1. 생태체계적 관점}

Bronfenbrener(1992)는 유기체를 제대로 이해하 기 위해서는 유기체가 상호작용하는 생태학적 환 경맥락에서 파악해야 한다고 주장하는 인간발달 생태학 모형을 제시하였다. 미시체계는 발달하고 있는 유기체의 특정한 물리적 특성을 지닌 주어 진 환경에서 경험하게 되는 활동, 역할, 대인관계 유형을 의미한다. 중간체계는 미시체계들간의 상 호작용으로, 인간이 참여하는 두 가지 이상의 환 경에서 일어나는 과정과의 연결성을 말한다. 외 체계는 유기체에게 영향을 주기는 하나 개인이 그 환경에 능동적으로 직접 참여하지는 않는다. 즉, 개인에게 직접적인 상관이 없이 개인이 상호 작용하는 가족이나 또 다른 타인에게 영향을 주 는 일들이 일어나는 장면을 의미한다. 마지막으 로 거시체계는 특정 문화에서 강조되는 철학이나 이데올로기이다. 이러한 거시체계는 하위문화나 문화전반의 수준에 존재하거나 혹은 존재할 수 있는 하위체계의 형식과 내용의 일관성이며, 또 한 그 일관성의 기초가 되는 신념체계와 이념도 
포함된다(Bronfenbrener, 최명선-김광웅에서 재 인용, 1998).

이처럼 생태체계적 관점은 한 개인을 다양한 수준의 주위 환경에 영향을 받는 복잡한 관계의 체계속에서 발달하는 것으로 보고 있으며, 개인 을 환경과 결부시켜 이들 상호간의 지속적인 상 호작용과 역동성을 다룸으로서 통합적 시각을 제 공한다(손화희 2004). 따라서 생태체계적 관점은 인간-환경간 평생을 통한 상호호혜적인 조절과정 에 초점을 맞추는 광범위한 접근으로서(손화희 정옥분 1999), 자살생각과 관련된 다양한 수준의 영향 변인을 이해할 수 있는 개념적인 틀을 제공 하고 있어 본 연구에서는 생태체계적 관점에서 자살생각 관련 변수를 파악하고자 하였다.

\section{2. 생태체계적 관점에서 본 자살생각 관련 변수}

Bronfenbrener(1992)의 생태체계적 관점에서 생 애주기별 자살관련 요인을 살펴보면, 주로 개인 적 차원인 유기체변수와 미시체계변수에 집중되 어 알려져 있다. 따라서 자살생각에 영향을 미치 는 중간체계나 외체계에 관한 연구는 많지 않으 며, 거시체계변수의 경우는 개인적 수준에서 설 문지나 인터뷰를 통해 측정하기 어려운 점이 있다.

먼저 유기체는 개인적 수준의 체계이다. 모든 연령대에서 자살의 원인으로 가장 많이 거론되는 유기체 변수로는 우울감과 절망감, 스트레스(강 상경 2010; 강은정 2005 ; 김현순 · 김병석 2008 ; 김효정 - 정미애 2010; 송영달 등 2010; 박현숙 구현영 2009; 이은진 등 2010; 최정민 2010; Kalichman et al. 2000; Wilson et al. 1995)를 들 수 있는데, 우울감과 절망감 스트레스는 모두 자 살생각을 높이는 위험요인이다. 연구에 따라 절 망감이 우울감보다 자살생각을 더 높인다는 연구 결과(김현순·김병석 2008; Beck et al. 1993)도 있고, 절망이 우울을 매개로 하여 자살생각을 높 인다는 연구(육성필 2002)도 있으며, 스트레스가 우울을 중간변수로 하여 자살생각에 영향을 미친 다는 연구(우채영 등 2010)도 있으나 우울감과 절망감, 스트레스가 자살생각의 위험요인임에는 이견이 없다.
미시체계는 개인의 삶에 직접적인 영향을 미 치는 환경 체계이다. 모든 연령대에서 자살과 관 련하여 가장 많이 거론되는 미시체계 변수로는 가족결속도와 자살의 가족력을 들 수 있다. 즉, 가족결속도는 아동과 청소년, 대학생(김효정 - 정 미애 2010; 박병금 2007; 이정윤 - 허재홍 2003; Garrison et al. 1991), 성인(강모성 등 2008), 노인 (송영달 등 2010)의 자살생각을 낮추는 것으로 알려져 있다. 따라서 가족결속력은 자살생각의 보호요인으로 작용한다고 볼 수 있다. 또한 본 연구에서는 자살의 가족력도 미시체계에 포함시 켰다. 미국의 SPRC(Suicide Prevention Resource Center 2011)에서는 자살의 가족력을 자살위험요 인으로 구분하였으나, 국내의 김효정과 정미애 (2010)의 연구에서는 자살의 가족력은 자살생각 과 유의한 관계가 발견되지 않았다. 그럼에도 가 족의 응집력, 가족기능, 가족스트레스와 같은 가 족간의 관계가 자살생각을 높인다는 선행연구에 근거하면, 자살한 가족이 있다는 것은 가족의 결 속력, 가족기능을 와해시키며 가족스트레스를 높 이는 작용을 할 것이기 때문에 자살의 가족력은 자살생각에 위험요인으로 작용할 것으로 예측된다.

중간체계는 미시체계간의 관계를 의미하는 것 으로 가족과 이웃, 가족과 학교, 이웃과 학교 등 개인의 삶에 영향을 미치는 미시체계간의 관계를 의미한다. 중간체계변수의 경우에는 각 연령집단 에 따라 다르게 된다. 이는 각 연령집단의 미시 체계가 서로 다르기 때문이다. 즉 청소년의 경우 에는 부모와 학교 및 친구가 중요한 미시체계이 고, 성인에 경우에는 가정과 직장이 중요한 미시 체계이며, 노인의 경우에는 성인자녀와 친구 및 이웃이 중요한 미시체계이기 때문이다. 청소년의 경우에는 '청소년 부모의 친구에 대한 관심'을 중간체계변수로 잡았다. 청소년의 부모가 청소년 자녀의 친구에 대해서 관심이 있는 경우 자녀의 일상생활의 문제점 파악뿐 아니라 집밖에서의 자 녀행동에 대한 관찰 및 통제가 자연스럽게 이루 어진다는 점에서 이들 간의 관계 정도가 청소년 의 자살 생각의 보호요인으로 작용할 것이다. 성 인의 경우에는 '자신의 일에 대한 배우자의 관 심'을 중간체계변수로 잡았다. 성인은 다른 시기 
와 달리 직업스트레스가 자살에 영향을 미치는 변수(강모성 등 2008)로 거론되고 있다는 점을 고려하여, 내 직장이나 내 일에 대해서 배우자가 잘 알고, 관심을 가지고 있는 경우 자살생각이 감소될 것으로 예측된다. 따라서 성인의 경우에 는 '배우자의 내 일에 대한 관심'을 중간체계변 수로 잡았다. 노인의 경우에는 '노인의 이웃 및 친구에 대한 성인자녀와의 관심를 을 중간체계 변수로 잡았다. 즉 노인의 이웃 및 친구와 성인 자녀간의 관계는 여성독거노인의 삶의 질에 긍정 적인 영향을 미친다는 김윤정 등(2008)의 연구결 과를 확장시켜보면, 노인의 이웃 및 친구와 성인 자녀와의 관계는 자살생각도 감소시키는 보호요 인으로 작용할 것으로 예측된다.

외체계변수는 개인에게 직접적인 영향을 미치 진 않으나 간접적인 영향을 미치는 환경적 변수 이다. 예를 들어, 부모의 직장은 부모에게는 미시 체계이나 자녀에게는 외체계에 속하는 것이다. 자살생각에 영향을 미치는 외체계변수로는 거주 지역을 들 수 있다. 농촌의 자살률이 도시의 자 살률 보다 높으며(심영희 1986), 유정균(2008)은 20대에서 50대 성인의 경우 농촌지역에 거주하는 경우 자살율이 높고, 노인의 경우는 중소도시 및 농촌에 거주하는 경우 자살률이 높다고 밝혔다. 또한 높은 도시화수준이 자살률을 낮춘다는 연구 (Stack 2000)도 있다. 따라서 농촌지역에의 거주 는 자살의 위험요인으로 작용할 것으로 보인다. 한편, 지역사회의 결속정도가 자살율과 관련된다 는 김순규(2008)의 연구에 근거해 보면 우울감이 나 절망감, 스트레스, 가족과의 상호작용상의 문 제로 상담이 필요할 때 지역에 상담센터가 있는 가도 자살생각과 관련될 것이며, $\operatorname{SPRC(2011)ㅇㅔㅅㅓ~}$ 도 건강 및 정신건강관리의 접근성을 자살의 보 호요인으로 보고 있어, 지역의 상담센터 유무를 외체계변수에 포함시켰다. 또한, 사회 환경적 측 면에서는 '대중매체의 영향을 들 수 있다. 즉, 대중매체에서 유명연예인의 자살보도는 모방 자 살 혹은 베르테르 효과라 불리우며 청소년의 자 살에 영향을 미치는 것으로 알려져 있으며(김순 규 2008), 자살보도가 늘어날수록 자살사건이 증 가하며(김병철 2010), $\mathrm{SPRC(2011)에서도} \mathrm{미디어}$
의 영향을 자살의 위험요인으로 분류하였기 때문 에, 본 연구에서도 대중매체의 영향을 자살생각 의 위험요인으로 분류하고자 한다.

마지막으로 거시체계는 한 사회의 문화나 가 치관, 사회구조와 관련된 것으로서 자살에 영향 을 미치는 거시체계변수로는 경제위기, 경제성장 율, GNP, 여성의 경제참여율, 실업율, 조이혼율, 출생율 등을 들 수 있다(노용환 2005). 그러나 이 러한 변수들의 경우 개인을 대상으로 한 본 연구 에서 측정한다는 것이 의미가 없기 때문에 본 연 구에서는 제외하였다.

\section{3. 자살생각의 위험요인과 보호요인}

자살생각에 영향을 미치는 변수가 다양한데 이러한 변수들을 자살생각의 위험요인과 보호요 인으로 나누어 볼 수 있다. 위험요인은 자살생각 을 높이는 역할을 하며, 보호요인은 위험요인에 예방적인 역할을 하며 자살위험을 수정할 수 있 는 내적 - 외적자원(Fraser et al. 2001)이다. 따라 서 앞서 분석한 자살생각과 관련된 선행연구에 근거하여 자살의 위험요인으로는 우울감, 절망감, 스트레스, 자살의 가족력, 거주지역(농촌지역거 주), 대중매체의 영향을, 자살의 보호요인으로는 가족결속력과 중간체계변수(청소년의 경우에는 부 모의 청소년 친구에 대한 관심, 성인의 경우에는 배우자의 일에 대한 관심, 노인의 경우에는 성인 자녀의 노인의 친구나 이웃에 대한 관심), 상담 센터유무로 조작적 정의내리고자 한다.

\section{III. 연구방법}

\section{1. 자료수집절차}

자료수집은 제주도를 제외한 전국 10 개 지역 (서울특별시, 인천광역시, 경기도, 강원도, 충청남 도, 충청북도, 경상북도, 경상남도, 전라북도, 전 라남도)에 거주하는 청소년과 성인, 노인을 대상 으로 하여 설문조사를 실시하였다. 청소년의 경 우 각 지역의 중·고등학교의 교사를 통해서 설 문조사를 실시하였고, 성인의 경우 각 지역의 평 생학습센터, 각 대학의 평생교육원, 문화센터와 사회복지관 등의 기관의 직원에게 협조를 구했 
다. 또한 $\mathrm{H}$ 대학의 대학생을 조사원으로 활용하 여 각 지역사회에 거주하는 성인에 대한 설문조 사도 병행하였다. 노인을 대상으로 한 설문조사 를 위해서는 각 지역의 노인복지회관, 노인종합 복지관 및 보건소 등의 사회복지사와 간호사 및 직원을 활용하여 기관의 협조를 통해 설문조사를 하였다.

설문조사 시 각 지역 및 생애주기, 성별의 비 율을 맞추고자 하였다. 즉, 10 개 지역별로 대략 130 부 정도의 설문을 배부하였는데 이 때 청소 년, 성인, 노인을 각 각 일정 비율로 배분하였으 며, 남녀 성별도 유사하게 배분되도록 하였다. 예 를 들어 서울 지역의 경우 남자 청소년 20 부, 여 자청소년 20 부, 남자 성인 25 부, 여자 성인 25 부, 남자 노인 20 부, 여자 노인 20 부를 배분하여 설 문조사를 실시하였다. 총 청소년 400부, 성인 500 부, 노인 400 부를 설문조사하였고, 응답이 부실한 설문지를 제외한 뒤, 청소년 393부, 성인 473부, 노인 376부 총 1246 부를 최종분석에서 사용하 였다.

\section{2. 측정도구}

모든 측정도구는 점수가 높을수록 그러한 경 향이 강한 것을 의미한다.

\section{1) 자살생각}

자살생각을 측정하기 위해 Harlow 등(1986)의 Suicide Ideation Scale을 번역한 김형수(2002)의 척도에 '때때로 아무런 이유 없이 죽고 싶다는 생각이 들 때가 있다'는 문항을 추가하여 5 문항 의 5 점 리커트형 척도로 측정하였다. 척도의 신 뢰도 Cronbach's a 값은 .93이다

\section{2) 유기체변수}

유기체변수는 개인적 수준의 체계로서 절망감, 우울감, 스트레스를 측정하였다.

먼저 절망감은 Beck과 Weissman(1974)이 개발 한 Beck Hopelessness Scale(BHOP)을 배지연(2004) 이 수정한 도구로서 총 10 문항의 5점 리커트형 척도이며, 신뢰도 Cronbach's a값은 .90이다. 우울
감은 SCL-90의 하위척도로 Choi(1992)가 번역한 것으로 10 문항이다. 본래 4점 척도로 구성되어 있으나, 본 연구에서는 5점 리커트형 척도로 수 정하였으며, 신뢰도 Cronbach's a 값은 .94이다. 스트레스는 한국어판 스트레스 측정도구인 BEPSI-

$\mathrm{K}$ (Brief Encounter Psychosocial Instrument-Korean) 를 사용하였다. BEPSI-K 는 5 문항으로 구성되어 있고 5점 리커트형 척도이며 척도의 신뢰도 Cronbach's a 값은 .82이다

\section{3) 미시체계변수}

미시체계변수는 자살의 가족력과 가족결속도 로 측정하였다. 자살의 가족력은 조부모를 포함 한 가족 중에 자살을 했거나 시도하신 분이 있는 가에 있다(1점), 없다(0점)으로 응답하게 하였다. 가족결속도는 Olson, Portner와 Lavee $(1985,1990)$ 에 의해 개발된 FACES 시리즈를 김수현(1998)이 종합, 재구성한 척도를 사용하였다. 10문항 5점 리커트형 척도로 신뢰도 Cronbach's a 값은 .92 이다.

\section{4) 중간체계변수}

중간체계변수는 청소년과 성인, 노인에게 각기 다른 문항으로 질문하였다. 먼저 청소년에게는 '귀하의 부모님은 귀하의 친구에 대해서 어느 정 도 관심이 있습니까?’을 물었고, 성인에게는 ‘귀 하의 배우자는 귀하의 일에 대해서 어느 정도 관 심이 있습니까?’을 물었으며, 노인에게는 ‘귀하의 자녀는 귀하의 친구나 이웃에 대해 어느 정도 관 심이 있습니까?'물었다. 각기 1문항씩이고 5점 리 커트형으로 구성하였다.

\section{5) 외체계변수}

외체계변수는 거주지와 지역의 상담센터 유무, 대중매체의 영향을 측정하였다. 거주지는 현재 대상자가 살고 있는 지역으로 대도시, 중소도시, 농촌으로 구분하여 측정하였고, 지역의 상담센터 유무는 '있다', ‘없다'로 측정하였다. 대중매체의 영향은 대중매체(TV, 라디오, 신문, 인터넷 등)를 통해 연예인 및 유명인 혹은 다른 사람의 자살에 
대한 보도를 접한 뒤 자살충동을 느낀 적이 있는 가에 대해 ‘그렇다', ‘아니다’로 응답하게 하였다.

\section{3. 연구대상의 특성}

본 연구의 대상은 청소년(중학생과 고등학생) 399명, 성인(30세에서 55세) 473명, 노인(65세 이 상) 376 명의 3 집단으로서 연구대상의 특성은 Table 1 과 같다.

여성이 전체의 $53.8 \%$ 이고 남성이 $46.2 \%$ 로 여 성이 약간 더 많다. 평균연령은 42.03세이고 19세 미만이 전체의 $32.3 \%$ 로 가장 많다. 교육수준은 고등학교 재학과 졸업이 $32.0 \%$ 로 가장 많은데 이는 청소년과 성인이 함께 포함되어 있기 때문 이다. 또한 무교(기타종교 포함)가 $39.9 \%$ 로 가장 많고 그 다음이 기독교인으로 전체의 $31.7 \%$ 이다. 주관적 경제 상태에 대한 인식을 보면 '보통'이 라는 응답이 전체의 $57.7 \%$ 로 절반을 약간 상회 한다.

Table 1. Demographic Characteristics of Study Subjects

$(\mathrm{N}=3,213)$

\begin{tabular}{|c|c|c|c|c|}
\hline Variable & Categories & $\mathrm{N}$ & $\%$ & Mean \\
\hline \multirow{2}{*}{ Gender } & Male & 573 & 46.2 & \multirow{2}{*}{ - } \\
\hline & Female & 666 & 53.8 & \\
\hline \multirow{7}{*}{ Age(yr) } & -19 & 401 & 32.3 & \multirow{7}{*}{$\begin{array}{c}42.03 \\
(23.19)\end{array}$} \\
\hline & $20-29$ & 30 & 2.4 & \\
\hline & $30-39$ & 174 & 14.0 & \\
\hline & $40-49$ & 189 & 15.2 & \\
\hline & $50-59$ & 60 & 4.8 & \\
\hline & $60-69$ & 175 & 14.1 & \\
\hline & $\geq 70$ & 211 & 17.0 & \\
\hline \multirow{5}{*}{ Education } & illiteracy & 68 & 5.5 & \\
\hline & elementary & 133 & 10.8 & \\
\hline & middle & 263 & 21.3 & \\
\hline & high & 407 & 32.0 & \\
\hline & more university & 364 & 29.5 & \\
\hline \multirow{4}{*}{ Religion } & christian & 390 & 31.7 & \\
\hline & buddhism & 235 & 19.1 & \\
\hline & catholic & 114 & 9.3 & \\
\hline & others & 492 & 39.9 & \\
\hline Subjective & insufficiency & 360 & 29.3 & \\
\hline economic & average & 714 & 57.7 & \\
\hline status & sufficiency & 161 & 12.9 & \\
\hline
\end{tabular}

\section{4. 자료분석}

연구결과를 분석하기 위해 SPSS 17.0 을 이용 하였으며 구체적인 분석과정을 다음과 같다. 먼 저 빈도분석을 통해 사회인구학적 특성을 파악하 고 척도의 신뢰도를 산출하기 위해 Cronbach's a 값을 산출하였다. 둘째, 생애주기별 자살생각실 태를 파악하기 위해 평균(표준편차)과 빈도를 산 출하였다. 셋째, 생애주기에 따른 생태체계변수 의 차이를 파악하기 위해 oneway ANOVA를 실 시하고 사후검증으로는 Duncan's test를 하였으며, 또한 교차분석도 실시하였다. 넷째, 생애주기별 자살생각에 영향 미치는 생태체계변수의 위험요 인과 보호요인을 파악하기 위해 먼저, 상관관계 분석을 통해 다중공선성을 확인하였고, 그 다음 으로는 위계적 회귀분석을 실시하였다.

\section{IV. 연구결과}

\section{1. 생태체계변수의 수준}

자살생각은 5 점 만점에 1.78 점으로 낮은 수준 이다. 유기체변수 중 우울감은 2.45점 절망감은

Table 2. Status of Variables

\begin{tabular}{llc}
\hline \multicolumn{3}{c}{ Characteristics $\mathrm{n}(\%)$ or $\mathrm{M}(\mathrm{SD})$} \\
\hline Sucide ideation & $1.73(0.80)$ \\
\hline \multirow{2}{*}{ Organic } & depression & $2.45(0.78)$ \\
system & hopelessness & $2.35(0.70)$ \\
& stress & $3.08(0.84)$ \\
\hline \multirow{3}{*}{ Micro } & family cohesion & $3.54(0.72)$ \\
system & family history of suicide & \\
& yes & $72(6.0)$ \\
Intermediate & system & $1125(94.0)$ \\
\hline \multirow{4}{*}{ no } & $3.37(0.94)$ \\
& residence & $489(39.5)$ \\
& large city & $528(42.6)$ \\
& small city & $221(17.6)$ \\
Mezo & rural & \\
system & counselling center & $909(74.1)$ \\
& yes & $318(25.9)$ \\
& no & $91(7.4)$ \\
& influence of mass media & $1140(92.6)$ \\
\hline & yes & no
\end{tabular}


2.35점으로 중앙값인 3점 이하이며 스트레스는 3.08점으로 중앙값 이상이다. 미시체계변수인 자 살시도가족의 유무를 보면, 자살시도 가족이 있 다고 응답한 경우가 전체의 $6.0 \%$ 였다. 또한 가족 의 결속력은 3.54점으로 중앙값 이상이며, 중간체 계변수도 3.37 점으로 중앙값이상이다. 외체계변 수 중 거주지를 보면 중소도시에 거주하는 경우 가 $42.6 \%$ 로 가장 많고 대도시에 거주하는 경우 가 $39.5 \%$, 농촌지역에 거주하는 경우가 $17.6 \%$ 이 다. 상담기관은 '있다'는 응답이 $74.1 \%$ 이며, 전체 의 $92.6 \%$ 가 자살과 관련된 보도를 접하고 자살 충동을 느끼지 않는 것으로 나타났다(Table 2).

\section{2. 생애주기에 따른 생태체계변수의 차이}

먼저 자살생각을 보면, 노인, 청소년, 성인 순 으로 노인의 자살생각이 가장 높았다. 유기체 변 수 중 우울감과 절망감은 노인, 청소년, 성인 순 으로 노인의 우울감과 절망감이 가장 높았고, 성
인의 우울감과 절망감이 가장 낮았다. 스트레스 의 경우는 노인, 성인, 청소년 순으로 노인의 스 트레스가 가장 높은 것은 다른 유기체변수와 마 찬가지이나 청소년의 스트레스 수준이 가장 낮다 는 점에서는 우울감이나 절망감과는 다른 양상 이다.

다음으로 미시체계변수 중 가족결속력은 다른 생태체계변수 중에서 평균점수가 높은 변수로서, 성인, 노인, 청소년 순으로 성인이 가족결속력을 가장 높게 인식하였으며 청소년이 가장 낮게 인 식하였다. 자살시도가족유무는 집단 간 차이가 유의미하지 않았다.

중간체계변수는 전반적으로 3 점대 이상으로서, 청소년, 성인, 노인 순으로 나타났다. 즉, 청소년 이 부모와 자신의 친구간의 친밀감을 다른 집단 에 비해 가장 높게 인식하였으나 노인은 자신의 친구나 이웃에 대한 성인자녀의 관심 정도가 낮 은 것으로 인식하고 있었다.

Table 3. Differences in ecological system variables through life course

\begin{tabular}{|c|c|c|c|c|c|c|c|}
\hline & & & $\begin{array}{c}\text { Adolescent } \\
\mathrm{n}(\%) / \mathrm{M}(\mathrm{SD})\end{array}$ & $\begin{array}{l}\text { Adult } \\
\mathrm{n}(\%) / \mathrm{M}(\mathrm{SD})\end{array}$ & $\begin{array}{c}\text { Elderly } \\
\mathrm{n}(\%) / \mathrm{M}(\mathrm{SD})\end{array}$ & $\mathrm{F} / \mathrm{x}^{2}$ & Duncan \\
\hline \multicolumn{3}{|c|}{ Sucide ideation } & $1.80(0.96)$ & $1.50(0.62)$ & $1.94(0.71)$ & $36.99^{* * *}$ & $\mathrm{~b}, \mathrm{a}, \mathrm{c}$ \\
\hline \multirow{3}{*}{$\begin{array}{l}\text { Organic } \\
\text { system }\end{array}$} & \multicolumn{2}{|l|}{ depression } & $2.50(0.85)$ & $2.19(0.64)$ & $2.71(0.76)$ & $50.85^{* * *}$ & $\mathrm{~b}, \mathrm{a}, \mathrm{c}$ \\
\hline & \multicolumn{2}{|l|}{ hopelessness } & $2.41(0.71)$ & $2.01(0.56)$ & $2.73(0.63)$ & $135.17^{* * *}$ & $\mathrm{~b}, \mathrm{a}, \mathrm{c}$ \\
\hline & \multicolumn{2}{|l|}{ stress } & $2.96(0.94)$ & $3.08(0.77)$ & $3.20(0.79)$ & $7.98^{* * *}$ & $\mathrm{a}, \mathrm{b}, \mathrm{c}$ \\
\hline \multirow{3}{*}{$\begin{array}{l}\text { Micro } \\
\text { system }\end{array}$} & \multicolumn{2}{|c|}{ family cohesion } & $3.36(0.79)$ & $3.73(0.59)$ & $3.48(0.72)$ & $32.76^{* * *}$ & $\mathrm{a}, \mathrm{c}, \mathrm{b}$ \\
\hline & family & yes & $16(4.1)$ & $29(6.7)$ & $27(7.3)$ & 406 & \\
\hline & \multicolumn{2}{|c|}{ history of suicide no } & $377(95.9)$ & 406(93.3) & $342(92.7)$ & 4.00 & \\
\hline \multicolumn{3}{|c|}{ Intermediate system } & $3.53(0.94)$ & $3.39(0.99)$ & $3.18(0.86)$ & $13.61^{* * *}$ & $\mathrm{c}, \mathrm{b}, \mathrm{a}$ \\
\hline \multirow{10}{*}{$\begin{array}{l}\text { Mezo } \\
\text { system }\end{array}$} & \multirow{4}{*}{ residence } & large city & $163(41.1)$ & $245(52.0)$ & $81(21.9)$ & \multirow{4}{*}{$121.40^{* * *}$} & \\
\hline & & small city & $169(42.6)$ & $190(40.3)$ & $169(45.7)$ & & \\
\hline & & rural & $65(16.4)$ & $36(7.6)$ & $120(32.4)$ & & \\
\hline & & total & $397(100)$ & $471(100)$ & $370(100)$ & & \\
\hline & \multirow{3}{*}{$\begin{array}{l}\text { counselling } \\
\text { center }\end{array}$} & yes & $218(55.3)$ & $378(81.6)$ & $313(94.6)$ & \multirow{3}{*}{$107.24^{* * *}$} & \\
\hline & & no & $176(44.7)$ & $85(18.4)$ & $57(15.4)$ & & \\
\hline & & total & $394(100)$ & $463(100)$ & $370(100)$ & & \\
\hline & \multirow{3}{*}{$\begin{array}{l}\text { influence of } \\
\text { mass media }\end{array}$} & yes & $25(6.4)$ & $23(4.9)$ & $43(11.7)$ & \multirow{3}{*}{$14.66^{* * *}$} & \\
\hline & & no & 367(93.6) & $447(95.1)$ & $326(88.3)$ & & \\
\hline & & total & $392(100)$ & $470(100)$ & $369(100)$ & & \\
\hline
\end{tabular}

$* * \mathrm{p}<.01, * * * \mathrm{p}<.001$ 
외체계변수를 살펴보면, 청소년은 대도시와 중 소도시에 거주하는 비율이 비슷하고, 성인은 대 도시에 거주하는 비율이 높으며, 노인은 중소도 시에 거주하는 비율이 높다. 이는 표집상의 문제 이다. 본 연구에서는 전국에 걸친 설문조사를 하 였으나 이 때 대도시와 중소도시 및 농촌지역에 대한 할당을 한 것은 아니기 때문에 대도시와 중 소도시의 비율이 높은 것으로 보인다. 상담기관 유무에 대해서는 청소년과 성인, 노인 모두 상담 기관이 ‘있다'고 응답하는 비율이 높으나 청소년 에 비해 성인과 노인의 경우 그 비율이 월등히 높다. 마지막으로 대중매체의 영향을 보면, '없 다'는 응답이 '있다'는 응답에 비해 월등이 높으 나, 다른 집단에 비해 노인의 경우는 자살보도를 접한 후 자살충동을 느낀 적이 있다는 비율이 더 높은 것으로 나타났다. 따라서 노인이 청소년이 나 성인에 비해 대중매체의 영향을 더 많이 받는 것으로 보인다(Table 3).

\section{3. 생애주기별 자살생각에 영향 미치는 생태} 체계변수의 위험요인과 보호요인

생애주기별 자살생각에 영향을 미치는 생태체 계변수의 위험요인과 보호요인을 살펴보기 위한 위계적 회귀분석 전에 상관관계분석을 통해 다중 공선성을 확인하였다. Table 4 에서 보는 바와 같
이 상관계수는 .00 에서 .71 까지 다중공선성은 없 는 것으로 보인다. 다음으로는 생애주기별 자살 생각에 영향을 미치는 생태체계변수의 상대적 영 향력을 살펴보기 위해 위계적 회귀분석을 실시하 였다(Table 5). Durbin-Watson 값은 1.75에서 2.09 로 독립적임을 알 수 있다.

청소년의 경우 유기체변수가 청소년의 자살생 각을 설명하는 설명력은 $44 \%$ 로 상당히 높으며, 미시체계변수가 청소년의 자살생각을 설명하는 설명력은 $1 \%$ 였다. 다음으로 중간체계변수가 청 소년의 자살생각을 설명하는 설명력은 $0 \%$ 이며, 마지막으로 외체계변수가 청소년의 자살생각을 설명하는 설명력은 $4 \%$ 로 나타났다. 청소년의 자살생각에는 유기체변수의 설명력이 가장 높았 다. 4단계 9 개 변수는 청소년의 자살생각을 $48 \%$ 설명하였다. 4 번째의 최종모델을 중심으로 보다 구체적으로 설명하면, 청소년의 우울감이 높을수 록, 스트레스가 높을수록, 그리고 대중매체의 영 향이 있다고 응답한 경우 자살생각이 높아지는 것으로 나타났다. 가족결속력의 경우 외체계변수 의 투입과 함께 그 영향력이 사라졌으나 가족결 속력이 높을수록 자살생각이 낮아지는 것으로 나 타났다. 9 개의 변수 중 우울감의 영향력이 가장 높았다(Table 5).

다음으로 성인의 경우 유기체변수가 성인의

Table 4. Correlations

\begin{tabular}{|c|c|c|c|c|c|c|c|c|c|}
\hline & 1 & 2 & 3 & 4 & 5 & 6 & 7 & 8 & 9 \\
\hline \multicolumn{10}{|l|}{ 1. Sucide ideation } \\
\hline 2. Depression & $.63^{* * *}$ & & & & & & & & \\
\hline 3. Hopeless & $.46^{* * *}$ & $.71^{* * *}$ & & & & & & & \\
\hline 4. Stress & $.41^{* * *}$ & $.50^{* * *}$ & .37 & & & & & & \\
\hline 5. Family Cohesion & $-.38^{* * *}$ & $-.38^{* * *}$ & $-.42^{* * *}$ & $-.22^{* * *}$ & & & & & \\
\hline 6. Family history of suicide ${ }^{a}$ & .04 & .02 & .03 & .03 & .00 & & & & \\
\hline 7. Intermediate system & $-.20^{* * *}$ & $-.26^{* * *}$ & $-.26^{* * *}$ & $-.17^{* * *}$ & $.30^{* * *}$ & $-.07^{*}$ & & & \\
\hline 8. Residence $^{\mathrm{a}}$ & $-.06^{*}$ & $-.07^{* * *}$ & -.04 & $.08^{*}$ & .03 & -.03 & -.02 & & \\
\hline 9. Counselling center ${ }^{a}$ & -.05 & $-.07^{*}$ & $-.06^{*}$ & -.00 & $.11^{* * *}$ & $.07^{*}$ & $.08^{* *}$ & -.12 & \\
\hline 10. Mass media ${ }^{a}$ & $.42^{* * *}$ & $.33^{* * *}$ & $.26^{* * *}$ & $.14^{* * *}$ & $-.24^{* * *}$ & $.16^{* * *}$ & $-.15^{* * *}$ & $-.10^{*}$ & .03 \\
\hline
\end{tabular}

$* \mathrm{p}<.05, * * \mathrm{p}<.01, * * * \mathrm{p}<.001$

${ }^{\mathrm{a}}=$ dummy variable: Family history of suicide( $1=$ yes, $0=$ no); Residence( $1=$ Metro city, $0=$ other); Counselling center(1=yes, $0=$ no); Influence of mass media(1=yes, $0=$ no). 
자살생각을 설명하는 설명력은 $40 \%$ 였으며, 미 시체계변수가 성인의 자살생각을 설명하는 설명 력은 $0 \%$ 였다. 다음으로 중간체계변수가 성인의 자살생각을 설명하는 설명력은 $1 \%$ 였으며, 마지 막으로 외체계변수가 성인의 자살생각을 설명하 는 설명력은 $5 \%$ 로 나타났다. 성인의 자살생각에 는 유기체변수의 설명력이 가장 높았고, 4 단계 9 개 변수는 성인의 자살생각을 $46 \%$ 설명하였다. 4 번째의 최종모델을 중심으로 보다 구체적으로 설 명하면, 성인의 우울감이 높을수록, 거주지가 중 소도시나 농촌인 경우, 그리고 대중매체의 영향 이 있다고 응답한 경우 자살생각이 높아지는 것 으로 나타났으며, 9 개의 변수 중 우울감의 영향 력이 가장 높았다(Table 5).

마지막으로 노인의 경우 유기체변수가 노인의 자살생각을 설명하는 설명력은 $32 \%$ 였으며, 미 시체계변수가 노인의 자살생각을 설명하는 설명 력은 $5 \%$ 였다. 다음으로 중간체계변수가 노인의 자살생각을 설명하는 설명력은 $2 \%$ 였으며, 마지
막으로 외체계변수가 노인의 자살생각을 설명하 는 설명력은 $6 \%$ 로 나타났다. 따라서 노인의 자 살생각에는 유기체변수의 설명력이 가장 높았으 며, 4 단계 9 개 변수는 노인의 자살생각을 $45 \%$ 설 명하였다. 4 번째의 최종모델을 중심으로 보다 구 체적으로 설명하면, 노인의 우울감이 높을수록, 스트레스가 높을수록, 가족결속력이 낮을수록, 자살시도가족이 없는 경우, 자신의 친구 및 이웃 에 대해 성인자녀가 관심을 갖지 않을수록, 그리 고 대중매체의 영향이 있다고 응답한 경우 자살 생각이 높아지는 것으로 나타났으며, 9개의 변수 중 우울감의 영향력이 가장 높았다(Table 5).

따라서 청소년과 성인, 노인의 자살생각에 공 통적으로 영향을 미치는 변수는 우울감과 대중매 체의 영향이었으며, 청소년의 경우에는 스트레스 가, 성인의 경우에는 거주지가, 그리고 노인의 경 우에는 스트레스와 가족결속력, 자살시도가족유 무, 노인의 친구 및 이웃에 대한 성인자녀의 관 심이 각기 영향을 미치는 것으로 나타났다.

Table 5. Influence variables on suicide ideation through life course

\begin{tabular}{|c|c|c|c|c|c|c|c|c|c|c|c|c|}
\hline & \multicolumn{4}{|c|}{$\begin{array}{c}\text { Adolescent } \\
\text { sucide iideation }\end{array}$} & \multicolumn{4}{|c|}{$\begin{array}{c}\text { Adult } \\
\text { sucide ideation }\end{array}$} & \multicolumn{4}{|c|}{$\begin{array}{c}\text { Elderly } \\
\text { sucide ideation }\end{array}$} \\
\hline & $\beta$ & $\beta$ & $\beta$ & $\beta$ & $\beta$ & $\beta$ & $\beta$ & $\beta$ & $\beta$ & $\beta$ & $\beta$ & $\beta$ \\
\hline $\begin{array}{l}\text { Organic system } \\
\text { depression }\end{array}$ & $.52^{* * *}$ & $.51^{* * *}$ & $.51^{* * *}$ & $.43^{* * *}$ & $.56^{* * *}$ & $.55^{* * *}$ & $.55^{* * *}$ & $.46^{* * *}$ & $.40^{* * *}$ & $.36^{* *}$ & $.36^{* *}$ & $.34^{* *}$ \\
\hline hopeless & .01 & -.01 & -.01 & -.01 & .06 & .05 & .05 & .08 & $.12^{*}$ & .05 & .04 & .01 \\
\hline stress & $.20^{* * *}$ & $.19^{* * *}$ & $.19^{* * *}$ & $.19^{* * *}$ & .06 & .05 & .05 & .08 & $.13^{* *}$ & $.14^{* *}$ & $.13^{* *}$ & $.12^{* *}$ \\
\hline \multicolumn{13}{|l|}{ Micro system } \\
\hline family cohesion & & $-.09^{*}$ & $-.10^{*}$ & -.07 & & -.07 & -.09 & -.06 & & $-.24^{* * *}$ & $-.22^{* * *}$ & $-.18^{* * *}$ \\
\hline $\begin{array}{l}\text { family history of } \\
\text { suicide }^{\mathrm{a}}\end{array}$ & & .04 & .05 & .04 & & .04 & .04 & .01 & & -.00 & -.01 & $-.09^{*}$ \\
\hline Intermediate system & & & .03 & .01 & & & .06 & .05 & & & $-.16^{\text {** }}$ & $-.09^{*}$ \\
\hline \multicolumn{13}{|l|}{ Mezo system } \\
\hline residence $^{\mathrm{a}}$ & & & & .03 & & & & $-.12^{* *}$ & & & & .06 \\
\hline counselling center ${ }^{\mathrm{a}}$ & & & & .00 & & & & .00 & & & & .00 \\
\hline mass media $^{a}$ & & & & $.22^{* * *}$ & & & & $.22^{* * *}$ & & & & $.27^{* * *}$ \\
\hline $\mathrm{F}$ value & 101.15 & 62.47 & 52.07 & 40.25 & 78.79 & 48.01 & 40.44 & 33.97 & 58.15 & 43.33 & 37.89 & 32.31 \\
\hline $\mathrm{R}^{2}$ & $.44^{* * *}$ & $.45^{* * *}$ & $.45^{* * *}$ & $.48^{* * *}$ & $.40^{* * *}$ & $.40^{* * *}$ & $.41^{* * * *}$ & $.46^{* * *}$ & $.32^{* * *}$ & $.37^{* * *}$ & $.39^{* * *}$ & $.45^{* * *}$ \\
\hline $\mathrm{R}^{2}$ change & - & .01 & - & $.04^{* *}$ & - & - & .01 & $.05^{* *}$ & & $.05^{* *}$ & $.02^{* *}$ & $.06^{* * *}$ \\
\hline
\end{tabular}




\section{V. 논의 및 결론}

\section{1. 논의}

자살은 개인적인 사건이나 자살율의 급격한 증가로 사회적인 문제가 되고 있는 상황에서 자 살과 관련된 학문적 연구는 다수 진행되었으나 단편적인 변수에 초점을 두고 있거나 단일 연령 집단의 자살생각에 연구의 관심을 두고 있다는 한계점이 있다. 또한 자살의 분포가 전국적임에 도 불구하고 대상자 표집이 어느 특정지역으로 편중되어 있다는 제한점도 갖고 있다. 따라서 본 연구에서는 생애주기별로 자살생각과 관련된 다 양한 변수를 체계적으로 분석하기 위해, 전국에 거주하는 청소년, 성인, 노인 1246 명을 대상으로 하여 생태체계적 접근을 통해 자살생각의 위험요 인과 보호요인을 영향변수를 규명하고자 했다. 이러한 목적을 이루기 위해 Spss win 17.0을 이용 하여 빈도분석, Oneway ANOVA, Chi-squre test, 상관관계분석, 위계적 회귀분석을 실시하였다. 본 연구의 주요결과를 중심으로, 자살생각의 위 험요인과 보호요인에 초점을 두어 논의를 하면 다음과 같다. 특히 모든 생애에 있어 공통적인 자살생각의 위험요인과 보호요인은 무엇이고, 특 정 생애주기에만 영향을 미치는 자살생각의 위험 요인과 보호요인은 무엇인가에 초점을 두어 논의 를 하고자 한다.

첫째, 자살생각은 5점만점에 1.78점(1점 전혀 그렇지 않다, 2점 그렇지 않다)으로 낮은 수준이 다. 노인이 1.94점, 청소년이 1.80 점, 성인이 1.50 점 순으로 노인의 자살생각이 가장 높고, 성인의 자살생각이 가장 낮았다. 이는 다른 연구에 비해 유사하거나 낮은 수준으로 볼 수 있다. 기혼 중 년 남성을 대상으로 한 강모성 등(2008)의 연구 에서는 24.69점(14점-70점), 독거노인을 대상으로 한 송영달 등(2010)의 연구에서는 8.73점(0점-36 점)이었다. 그런데, 청소년기의 발달적 특성이 성 인으로 성장 후 정신사회적 기능 및 정신기능에 손상을 줄 가능성이 높다(Steinhausen \& Metske 2004)는 점을 고려하면 청소년기의 자살생각 1.80 점은 낮은 수치라고 볼 수 없다. 청소년기의 자
살생각이 성인기와 노년기까지 전 생애에 걸쳐 영향을 미칠 수 있다는 점에서 청소년기에 대한 자살예방은 다른 시기보다 먼저 이루어져야 할 것으로 보인다.

둘째, 본 연구에서 자살생각의 위험요인으로 분류한 우울감, 절망감, 스트레스, 대중매체의 영 향 점수가 다른 생애주기에 비해 노인의 점수가 가장 높았고 거주지 역시 청소년이나 성인에 비 해 중소도시에 거주하는 비율이 높았다. 반면, 자 살생각의 보효요인으로 분류한 가족결속력은 성 인이 가장 높았고, 중간체계변수(부모와 친구와 의 친밀감)는 청소년의 점수가 높았고, 상담센터 의 유무에 대해서는 청소년이 없다고 응답한 경 우가 가장 많았다. 따라서 노년기에 자살생각의 위험요인으로 분류했던 변수들의 점수가 가장 높 다는 것은 노인이 자살생각에 있어 취약한 집단 임을 보여 주고 있으며, 노인의 자살생각 점수가 다른 생애주기에 비해서 높다는 점도 이러한 본 연구의 해석에 일조를 하고 있다. 또한 노년기 자살률이 급증하고 있다는 통계청(2011)의 보도 도 본 연구결과와 같은 맥락이라고 볼 수 있다. 따라서 생의 마지막 단계를 살아가고 있는 노년 기에 대한 우리 사회의 관심이 필요함을 보여준다.

셋째, 각 생애주기별 체계변수의 상대적 영향 력을 보면 유기체 변수의 영향력이 절대적이었 다. 이는 생태체계적 변수에 관한 선행연구(김윤 정 등 2008; 손덕순 - 이홍직 2006)와 같은 결과 로서 개인의 삶에 영향을 미치는 유기체 변수의 중요성을 확인할 수 있었고, 자살생각을 낮추기 위한 서비스에서는 개인적 수준에 있는 유기체 변수의 위험성을 낮추는데 구체적인 목표를 둔 프로그램이 개발되고 제공될 필요가 있음을 보여 준다.

생애주기에 따라 자살생각의 위험요인과 보호 요인에는 공통점과 차이점이 있었다. 먼저, 우울 감과 대중매체의 영향력은 전 생애주기의 자살생 각에 가장 강력하면서도 부정적인 영향을 미치는 공통 변수였다. 우울감은 자살과 관련된 대다수 의 선행연구(김형수 2002; 송영달 등 2010)에서 자살의 위험요인으로 지적되어 온 변수이며, 성 인을 청년층, 장년층, 노인층의 세 집단으로 나누 
어 분석한 강은정(2005)의 연구에서도 20세 이상 전 연령층의 성인에게 공통적인 자살생각 위험요 인이었다. 따라서, 자살생각과 관련된 여러 체계 변수를 통제한 상태에서도 자살생각에 미치는 우 울의 영향력이 지속적이었다는 점은 우울증을 조 기에 발견하고 치료할 수 있는 정부차원에서의 체계적인 시스템을 구축할 필요가 있음을 보여주 는 결과로서 자살예방을 위해 가장 선행되고 치 료되어야 할 측면이라는 점에서는 논의의 여지가 없다.

또한 대중매체의 영향은 모든 생애주기에서 우울감 다음으로 자살생각의 강력한 위험요인이 었다. 자살보도를 많이 할수록 모방 자살이 증가 한다는, 즉 자살의 베르테르 효과를 주장한 Phillips(김병철에서 재인용 2010)의 주장을 뒷받 침하는 연구결과로 볼 수 있다. 또한 자살 보도 량이 증가하면 자살자 수가 증가한다고 밝힌 김 병철(2010)의 연구결과와 유사하다. 따라서 오늘 날 대부분의 사람들이 대중매체를 통해 자살이나 자살현상을 알게 되고 이에 따라 자살보도가 자 살유발의 매개체 혹은 방아쇠 역할(Tousignant et al. 2005)한다는 점을 고려하여 자살과 관련된 보 도를 함에 있어 보다 신중을 기해야 할 것이다. Pirkis 등(2010)은 오스트리아에서의 자살을 보도 하는 방식을 분석한 결과 2000년에 비해 2007년 에는 자살보도의 양은 증가하였으나 단순한 자살 사건만이 아니라 자살예방책, 자살예방프로그램 등 질적인 측면에서의 보도가 늘어났다고 하였는 데, 이는 미디어가 자살행동에 영향을 미치고 있 다는 점을 자각하였기 때문이라고 하였다. 그런 데, 우리나라의 경우 유명인들의 자살사건이 TV 나 라디오, 인터넷 매체를 통해 실시간으로 보도 가 됨으로써 전 국민의 관심을 집중시키는 경향 이 있어 자살을 부추키는 결과를 낳고 있다. 따 라서 우리나라 역시 연예인이나 사회지도층 등 이슈가 되는 자살사건을 보도함에 있어서 단순한 자살사건의 보도에 초점을 두어 모방자살을 양산 하기 보다는 자살생각이 있는 경우 도움을 받을 수 있는 자살예방센터나 정책 등을 보다 강조하 여 보도 해야 할 필요가 있다.

생애주기별 자살생각에 영향 미치는 특성 변
수를 살펴보면 청소년의 경우에는 스트레스가 위 험요인이었고, 외체계변수의 투입에 따라 그 영 향력이 사라졌으나 가족결속력은 자살생각을 감 소시켜주는 보호요인이었다. 청소년기의 스트레 스가 자살생각을 예측하는데 중요한 역할을 한다 는 사실은 이미 선행연구(김효정·정미애 2010; 박병금 2007; 이정윤 - 허재홍 2003; Garrison et al. 1991)를 통해 밝혀졌다. 청소년의 경우 성인에 비해 스트레스에 대한 대처능력이 급격히 붕괴되 는 취약성이 있으며 인지적으로 미숙하기 때문에 갈등을 해결하는 방편이나 현실도피를 위하여 충 동적으로 자살을 생각하게 된다(박광배 - 신민섭 1992). 특히 자살위험 집단 청소년은 스트레스 사건이 발생할 때 부정적인 대처전략을 사용하는 경향이 있으므로(손정남 2007), 자살위험이 높은 청소년을 선별하여 스트레스 상황에서 긍정적인 대처전략을 사용하도록 하는 교육프로그램이 제 공되어야 할 것이다. 다음으로 청소년의 가족결 속력은 자살생각의 보호요인이었다. 가족체계가 역기능적이거나 가족으로부터 정서적 지지를 받 지 못한 청소년은 그렇지 않은 청소년에 비해 내 적으로는 불안이나 우울, 적대감을 더 경험하고 외적으로는 학교문제와 대인간의 갈등, 비행행동 과 같은 사회적 부적응 행동, 자살과 같은 자기 파괴적 행동의 위험성이 증가된다(김효정·정미 애 2010). 또한, 청소년의 가족관계와 스트레스, 우울, 자살생각간의 관계가 서로 유기적(우채영 등 2010)임을 고려할 때 청소년의 자살생각을 낮 추고 궁극적으로 자살사망을 줄이기 위해서는 청 소년과 그 가족을 대상으로 하여 정신건강적인 측면과 복지적인 측면에서의 서비스 제공이 필수 적이다. 청소년 가족을 대상으로 하여 부모자녀 간 의사소통능력 향상이나 가족의 결속력 증가, 자살위험이 있는 청소년 자녀에 대한 긍정적인 지지 제공하기 등과 같은 다면적인 프로그램을 제공해야 할 것이다. 또한 청소년은 성인이나 노 인에 비해 자살생각에 영향 미치는 변수의 수가 적었다. 이는 청소년의 자살이 충동적이며 단일 이유에 의한다는 것을 암시하는 결과로서 감수성 이 풍부하고 예민한 청소년의 특성에 대비한 대 책이 필요하다. 즉 세심한 주의 집중을 통해 가 
정이나 학교에서 자살징후를 예견해야 하며 자살 징후가 발견되는 청소년에 대한 체계적 관리가 필요하다. 미국의 SPRC(2011)에서는 교사를 대상 으로 하여 자살위험요인과 예방요인에 관한 교육 을 실시하고 있는데 이러한 프로그램을 우리나라 의 학교현장에서도 필수적인 교사교육으로 포함 시킬 필요가 있다.

성인의 자살생각에 영향을 미치는 특성 변수 로는 거주지가 나타났다. 대도시에 거주 하는 성 인의 경우 중소도시나 농촌지역에 거주하는 성인 에 비해 자살생각이 낮았다. 즉 대도시에의 거주 가 자살생각의 보호요인으로 작용하고 있었다. 이는 높은 도시화수준이 자살률을 낮춘다는 $\operatorname{Stack}(2000)$ 의 연구나, 20 대에서 50 대 성인의 경 우 농촌지역에서의 자살율이 높다는 유정균(2008) 의 연구결과와 같은 맥락으로 이해할 수 있다. 특히 농촌지역의 경우 경제적으로는 일자리 및 소득기회의 부족, 특히 농수산물 시장개방으로 인한 농업 및 1 차 산업의 쇠퇴와 인구감소로 지 역경제의 활력저하가 심각하다. 사회문화적으로 는 실업과 저취업, 빈곤, 사회적 배제, 지역서비 스의 침식, 공동체적 배려의 붕괴, 변화에 대한 무기력 등이 문제로 되고 있다. 이에 따른 한국 의 농촌사회는 급속한 붕괴(유정균 2008)가 자살 생각과 연관될 수 있음을 추정할 수 있다.

노인의 자살생각에 영향을 미치는 특정 변수 로는 스트레스가 위험요인이었고, 가족결속력, 자살시도가족유무, 노인의 친구 및 이웃에 대한 성인자녀의 관심은 자살생각의 보호요인이었다. 자살에 관한 사회 심리적 관점을 강조한 Baumeister (1990)는 현실에 존재하는 스트레스를 견디지 못 하고 인지적 미성숙으로 인한 현실 도피적 문제 해결방법으로서 자살을 선택하게 된다고 하였는 데, 이러한 주장은 배지연(2004), 김형수(2002) 등 의 결과와 같다. 따라서 노인을 대상으로 하여 스트레스를 측정하고 스트레스 대처방안에 대한 정보제공을 통해 노년기 스트레스를 감소시킬 수 있는 제도적 보완이 필요하다. 우리나라처럼 가 족주의 가치관이 중시되는 사회속에서 가족간의 유대관계는 노년기의 삶에 있어서 절대적이다. 따라서 가족결속력이나 노인의 친구 및 이웃에
대한 성인자녀의 관심과 같은 노년기 가족관계는 자살생각의 보호요인으로 작용하고 있다. 이는 가족통합이 좋을수록 노인의 자살생각이 낮으며 (김형수 2002), 가족결속이 우울을 매개로 하여 자살생각에 영향을 미치며(배지연 2004), 가족갈 등이 노인자살의 중요 예측 요인(Waern et al. 2003)임을 보여주는 것이다. 또한, 배우자와 자식 에 대한 연대와 책임감은 상호간의 관심으로 이 어져 자살위험을 낮출 수 있다(유정균 2008)는 연구결과와도 같은 맥락이다. 따라서 노년기 자 살을 예방하기 위해서는 무엇보다도 노인이 가족 과 함께 살아갈 수 있는 방안을 마련해야 할 것 이다. 예를 들어 가족의 부양기능을 강화 할 수 있는 가족 상담 프로그램, 현재의 노인장기요양 보험제도의 확충을 통해 등급 외 노인에 대한 돌 봄 서비스 강화, 노인을 부양하는 가족에 대한 수당 및 세금 지원과 같은 경제적 지원 등을 통 해 노인에 대한 가족부양부담을 감소시켜 줌으로 서 노인의 가족내로의 통합을 지원할 필요가 있 다. 한편, 가족결속력이나 가족의 기능, 부모자녀 간의 의사소통이 자살생각과 관련된다는 점이나, $\mathrm{SPRC}$ (2011)에서 자살의 가족력을 자살의 위험요 인으로 분류한 점을 고려하여 자살한 가족이 있 다는 것은 자살생각의 위험요인이 될 것으로 예 측되었다. 그러나 본 연구 결과 자살의 가족력은 노년기 자살생각의 보호요인으로 작용하고 있었 다. 이는 자살한 가족으로 인해 남아 있는 가족 의 심리적 고통, 경제적 어려움이나 가족기능의 해체, 주변 사람들의 부정적인 인식 등, 남아있는 가족이 겪는 고통과 어려움을 지켜본 경험, 혹은 그러한 어려움을 본인이 겪은 경험 등이 자살생 각을 감소시킨 원동력으로 작용했을 것으로 해석 해 볼 수 있으나 이에 관해서는 많이 연구되지 않아 후속 연구가 필요하다. 또한, 노인의 경우 청소년이나 성인과는 달리 자살생각에 영향을 미 치는 변수가 많은데, 이는 노년기 자살의 원인이 복합적이며 따라서 그 현상을 이해하기 어렵다는 점을 보여주는 것이다. 따라서 노인을 대상으로 하여 통합적인 서비스를 제공할 수 있는 국가적 차원의 창구가 필요하다는 것을 제안한다. 물론 각 지역보건소나 관련 기관, 상담소 등에서 자살 
예방과 관련된 서비스를 제공하고 있으나 노년기 특성에 맞는 특화된 자살예방정책을 제공할 필요 가 있다.

\section{2. 결론 및 제언}

첫째. 자살생각은 5 점 만점에 1.78 점으로 낮은 편이었다. 둘째, 생애주기에 따라 자살생각, 유기 체변수 중 우울감, 절망감, 스트레스, 미시체계변 수 중 가족결속도, 그리고 중간체계변수, 거주지, 상담기관유무, 대중매체영향의 차이가 유의하였 다. 셋째. 각 생애주기별 체계변수의 상대적 영향 력을 보면 유기체변수가 자살생각에 미치는 영향 력이 절대적이었다. 모든 생애주기에서 우울감과 대중매체의 영향력은 자살생각의 위험요인이었 고, 청소년과 노인의 경우에는 스트레스도 위험 요인이었다. 보호요인을 살펴보면, 청소년의 경 우에는 미약하나 가족결속력이 자살생각의 보호 요인으로 작용하고 있었고, 성인의 경우 대도시 에의 거주, 노인의 경우에는 가족결속력과 자살 의 가족력, 성인자녀의 자신의 친구와 이웃에 대 한 관심(중간체계변수)이 자살생각의 보호요인이 었다.

본 연구의 결과를 토대로 다음과 같은 제언을 하고자 한다. 첫째, 각 생애주기에 적합한 자살생 각의 위험성을 낮추는 중재전략을 발전시킬 필요 가 있다. 즉, 우울감과 스트레스, 대중매체의 영 향으로부터 개인을 보호하기 위해 관련 교육프로 그램 및 상담을 제공해야 할 것이며, 중소도시나 농촌지역에 사는 성인의 자살생각을 낮출 수 있 는 방안을 고안해야 할 것이다. 또한, 노인의 경 우 가족결속력이나 성인자녀와의 관계를 향상시 킬 수 있는 교육을 제공할 것을 제안한다. 둘째, 청소년의 경우 자살생각의 보호요인이 뚜렷하지 않기 때문에 청소년을 대상으로 하여서는 청소년 의 특성에 적합한 변수를 고려한 반복 연구가 필 요함을 제안한다. 셋째, 본 연구에서는 생애주기 별 자살생각 위험요인과 보호요인을 비교하기 위 해, 각 생애주기별 특성변수를 모두 살펴보지는 못하였다. 예를 들어 노인의 경우 건강상태나 죽 음불안 등이 자살생각과 관련되고 성인의 경우 직업스트레스가 중요변수이며 청소년의 경우 학
업스트레스가 자살생각에 있어 중요변수이다. 따 라서 후속연구에서는 각 생애주기에 적합한 특성 변수를 모두 포괄한 연구가 수행되기를 제언한 다. 넷째, 회귀분석에 있어 각 연령집단의 중간체 계변수가 서로 달랐다. 따라서 집단 간 직접적인 비교에 무리가 있을 수 있음을 밝힌다. 후속 연 구에는 중간체계변수를 같은 변수로 구성할 수 있는 방안을 마련할 필요가 있다. 다섯째, 본 연 구에서는 외체계를 측정함에 있어 상담센터의 유 무를 측정하였는데 실제로 상담센터가 있는 것과 이용도는 별개의 차원일 수 있어 해석에 주의를 기울여야 할 것이다. 마지막으로 본 연구에서는 각 생애주기별로 자살생각의 보호요인과 위험요 인에 연구의 초점을 두면서, 보호요인이 위험요 인을 어떻게 중재할 수 있는가에는 분석의 초점 을 두지 않았다. 후속 연구에서는 이러한 점에도 학문적 관심을 갖는다면 자살생각을 중재할 수 있는 보다 구체적인 방안을 도출할 것으로 기대 된다.

\section{참고문헌}

강모성 - 전영주·손태홍(2008) 기혼 중년남성의 직 무 및 가족스트레스와 자살구상. 한국가족관계 학회지 13(1), 105-134.

강상경(2010) 우울이 자살을 예측하는가?:우울과 자 살태도 관계의 성별 - 연령 차이. 사회복지연구 41(2), 67-100.

강은정(2005) 연령계층별 자살생각과 관련된 요인. 보건복지포럼 107, 81-86.

김병철(2010) 자살에 영향을 미치는 사회적 예측 변수 연구: 자살에 관하나 언론 보도 내용을 중심으로, 한국언론학보 54(2), 346-442.

김수현(1998) 가족사정 척도 개발과 타당도 검증. 부산대학교 박사학위논문.

김순규(2008) 청소년 자살에 영향을 미치는 위험요 인과 보호요인-보호요인의 매개효과를 중심으 로-. 정신보건과 사회사업 29, 66-93.

김윤정 - 안정신 - 강인(2008) 생태학적 관점에서 본 여성독거노인의 삶의 질. 한국가족관계학회지 13(3), 23-42.

김현순 - 김병석(2008) 자살생각과 그 관련변수들 간이 구조적 관계모형검증. 한국심리학회지: 상 담 및 심리치료 20(2), 201-219.

김형수(2002) 한국노인의 자살생각과 관련요인 연 구. 한국노년학 22(1), 159-172.

김형수(2006) 생애주기별 자살현황과 예방대책-노인 
과 청소년 자살의 비교를 중심으로- 노인복지 연구 34, 271-292.

김효정 - 정미애(2010) 대학생의 가족기능과 자기효 능감이 자살생각에 미치는 영향. 한국간호교육 학회지 16(1), 43-50.

김효창(2006) 성인자살의 특성과 자살유형에 관한 연구. 한국심리학회지:사회문제 12(1), 15-33.

노용환(2005) 자살의 경제학적 분석-우리나라 시도 별 패널자료를 이용한 접근-. 경제학 연구 54 (3), 177-200.

박광배 - 신민섭(1992) 고등학생의 지각된 스트레스 와 자살생각. 한국심리학회지: 임상 $10(1), 298-$ 314.

박병금(2007) 청소년의 자살생각 관련 요인- 자아존 중감과 우울에 매개효과를 중심으로, 한국생활 과학회지 16(3), 505-522.

박현숙, 구현영 (2009) 청소년의 스트레스와 자살사 고와의 관계에서 부모-자녀간 의사소통의 완충 효과. 정신간호학회지 18(1), 87-94.

배지연(2004) 노인의 자살생각에 관한 인과모형. 대 전대학교 박사학위논문.

손덕순 · 이홍직(2006) 노인의 심리적 안녕감 결정 요인에 관한 연구-생태체계요인을 중심으로. 노 인복지연구 $31,181-205$.

신상진 - 조영태(2007) 사회적 자본과 자살충동, 건 강교육. 건강증진학회지 24(3), 35-49.

심영희(1986) 한국사회의 자살:사회학적 관점에서 본 이론과 실태. 한양대학교 정신건강연구소 4 , 49-71.

손정남(2007) 대학생의 자살생각 관련 요인에 대한 판별분석. 정신간호학회지 16(4), 267-275.

손화희(2004) 서울지역 노인의 건강증진행위와 관 련된 생태학적 변수에 관한 연구. 대한가정학 회지 42(12), 77-92.

손화희 - 정옥분(1999) 재가복지 수혜노인의 주관적 안녕감에 관한 생태학적 접근. 한국노년학 19 (1), 83-103.

송영달·손지아- 박순미(2010) 독거노인의 자살생 각에 영향을 미치는 생태체계적 요인분석. 한 국노년학 30(2), 643-660.

오진경 · 조영태·김창엽(2005) 2000년 우리나라 성 인 자살자의 인구사회학적 특성. 보건과 사회 과학 $18,191-210$.

우채영 - 박아청 - 정현희(2010) 성별 및 학교급에 따른 청소년의 인간관계, 스트레스, 우울과 자 살생각간의 구조적 관계. 교육심리연구 $24(1)$, 19-38.

유정균(2008) 노인자살률의 지역별 편차 : 가족불안 정성의 영향을 중심으로 한국인구학 $31(2), 21-$ 44.

육성필(2002) 자살관련변인의 탐색과 치료프로그램 개발. 고려대학교 박사학위논문.

이귀행 (2004). 자살의 심리학적 측면 생물치료정 신의학 $10(1), 11-14$.

이은진 · 배숙경 - 엄태영(2010) 독거노인 자살시도
에 대한 우울과 여가활동 참여의 영향에 관한 연구. 한국노년학 30(2), 615-628.

이정윤 - 허재홍(2003) 아동의 자살 생각에 영향을 미치는 가족 위험 요인. 청소년상담연구 11(2), 85-95.

임수영(1996) 중학생의 자살생각에 영향을 미치는 요인과 사회적 지지의 완충효과. 고려대학교 석사학위논문.

장지연 - 신동균(2010) 소득 양극화와 자살. 사회보 장연구 26(2), 1-21.

최명선 · 김광웅(1998) 경제위기하에서 아동의 스트 레스에 영향을 미치는 생태학적 변인의 구조분 석. 생활과학연구지(숙명여자대학교) 13(1), 1-20. 최정민(2010) 노인 스트레스와 자살생각에 관한 연 구: 탄력성의 조절효과를 중심으로 한국사회복 지조사연구 24, 233-253.

통계청(2011) 2009년 사망원인 통계 결과(2011. 07. 06). www. kostat.go.kr.

Baumeister RF(1990) Suicide as escape from self. Psychological Review 97(1), 90-113.

Beck AT, Steer RA, Beck JS, Newman CF(1993) Hopelessness, depression, suicidal ideation, and clinical diagnosis of depression. Suicide and Life-Threatening Behavior 23(1), 139-145.

Bronfenbrener U(1992) Ecolobical systems theory. London:Jessica Kingsley Publishers. 인간발달생태 학. 이영 옮김(1995) 서울: 교육과학사.

Choi HK(1992) The process of caregiving stress among Korean caregivers for elderly. Unpuplished doctorial dissertation. Conel University USA.

Fraser MW, Kirby LD, Smokowski PR(2001) Risk and resilience in childhood. In MW. Fraiser(Ed.), Risk and resilience in childhood: An ecolodical perspective(pp. 13-66). Washington DC: NASW Press.

Garrison CZ, Jackson KL, Addy CL, McKeown RE, Waller JL(1991) Sucidal behavior in young adolescents. American Journal of Epidemiology 133, 1005-1014.

Harwood D, Jacoby R.(2000) Suicide behavior among the elderly. In The international handbook of suicide and attempted suicide(pp. 275-291). London: Wiley.

Kalichman SC, Heckman T, Kochman A, Sikkema K, Bergholte J(2000) Depression and thoughts of suicide among middle-aged and older persons living with HIV-AIDS. Psychiatric Serveice 51(7), 903-907.

Lester D(1989) A depression paradox theory of suicide. Pesonality and Individual Difference 10. $1-18$.

Pirkis J, Blood RW, Dare A, Holland K(2010) The media monitoring project. Changes in media reporting of suicide and mental health and illness in Austrialia:2000/01-2006/07.(2011. 07. 06). http:// 
www.mindframe-media.info/client_images/900476.pdf. SPRC(2011) Sucide risk assessment.(2011. 07. 06). http://sprc.org/library/PrimerModule4/

Stack S(2000) Suicide: A 15-year review of the sociological literature part II:Modernization and social intergration perspectives. Suicide and Life-Threatening Behavior 30(2), 163-176.

Steinhausen HC, Metske CW(2004) The impact of sucidal ideation in preadolescence, adolescence, and young adulthood on psychosocial functioning and psychopathodology in young adulthood. Acta Psychiatr Scandal 110(6), 438-445.
Tousignant M, Mishara BL, Caillaud A, Fortin V, St-Laurent $\mathrm{D}(2005)$ The impact of media coverage of the suicide of a well-known Quebec reporter: The case of Gaetan Girourd. Social Science \& Media 60, 1919-1926.

Waern M, Rubenowitz E, Wihelmson K(2003) Predictors of sucide in the old elderly. Gerontology 49, 328-334.

Wilson KG, Stelzer J, Bergman JN, Kral MJ, Iany AM, Elliot CA(1995) Problem solving, stress, and coping in adolescent suicide attemps. Suicide and Life-Threatening Behavior 25, 241-252. 